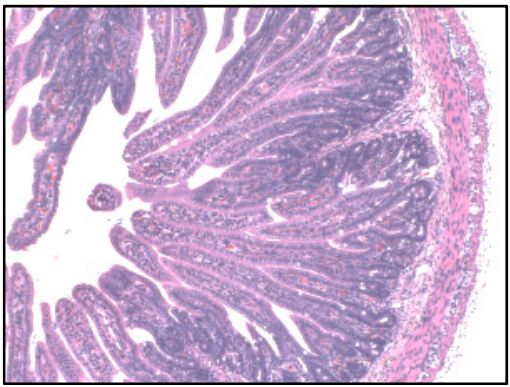

EA-Intact protein-No NEC

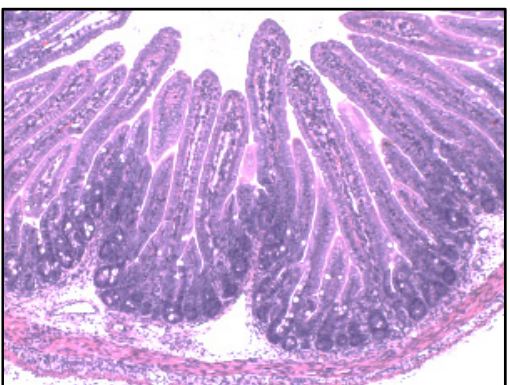

EA-Hydrolyzed protein-No NEC

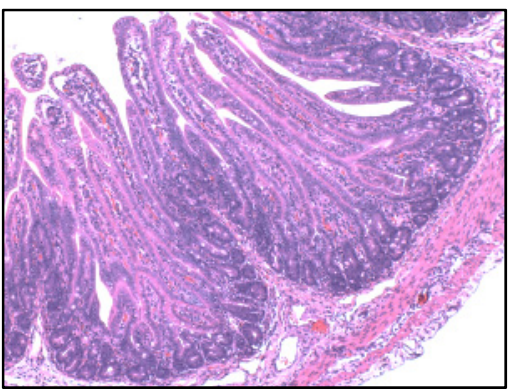

LA-Intact protein-No NEC

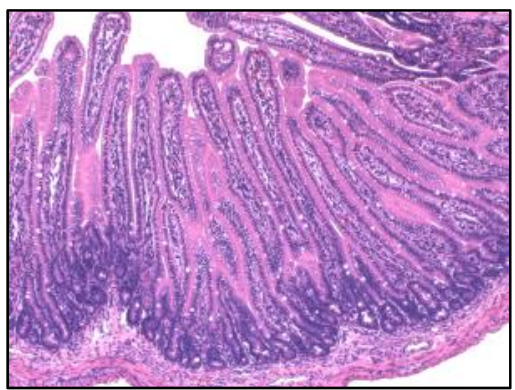

LA-Hydrolyzed protein-No NEC

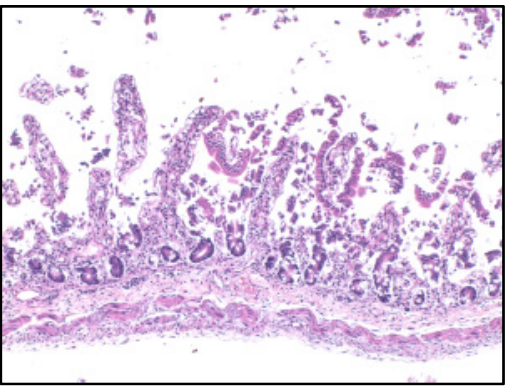

\section{EA-Intact protein-NEC}

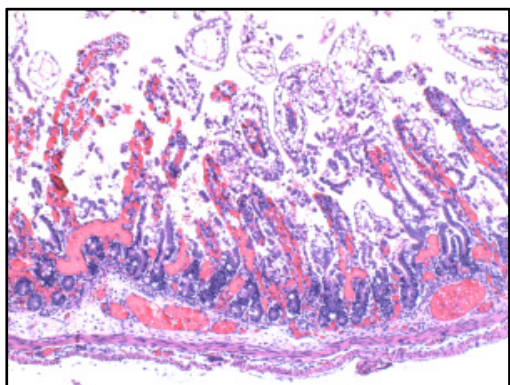

EA-Hydrolyzed protein-NEC

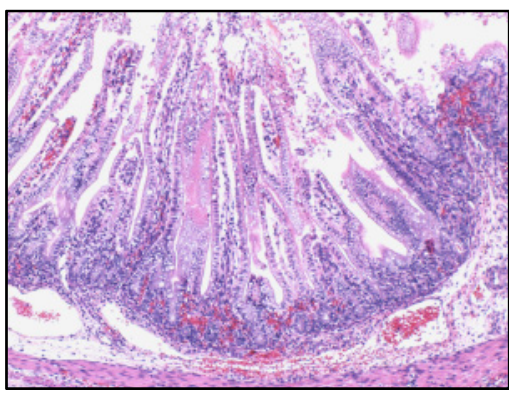

LA-Intact protein-NEC

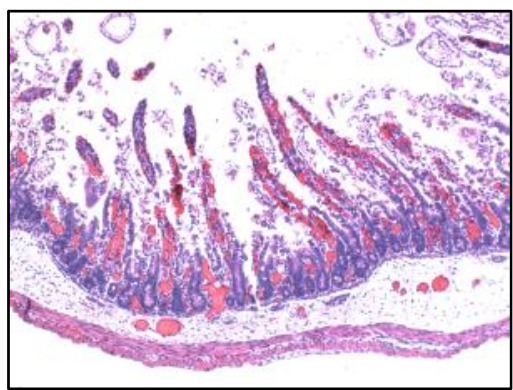

LA-Hydrolyzed protein-NEC

Panel A

Figure S2 


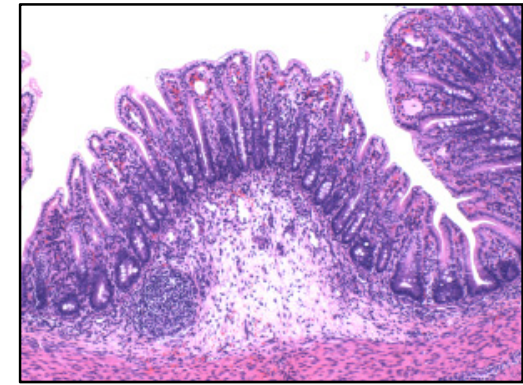

EA-Intact protein-No NEC

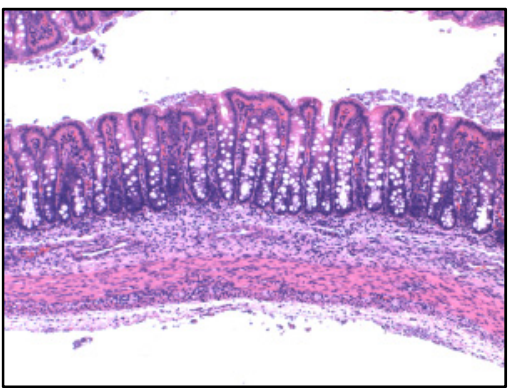

EA-Hydrolyzed protein-No NEC

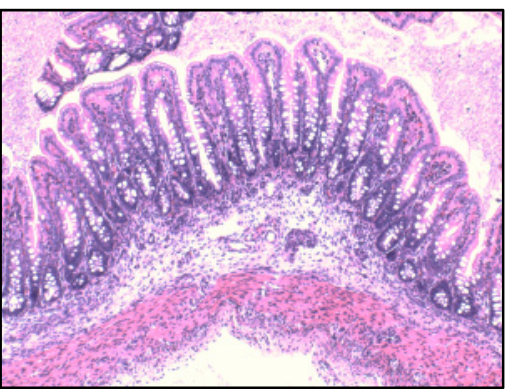

LA-Intact protein-No NEC

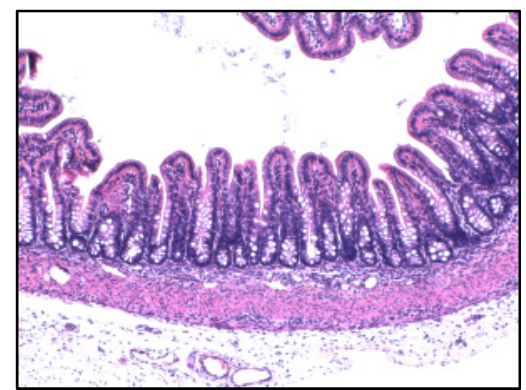

LA-Hydrolyzed protein-No NEC

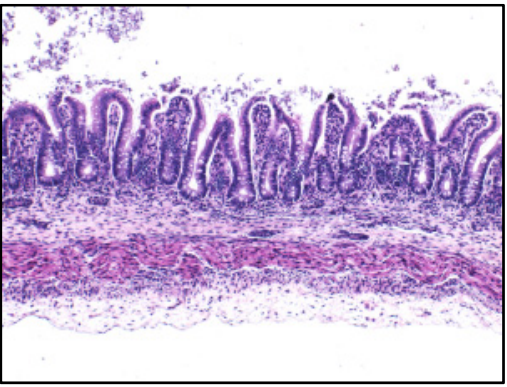

EA-Intact protein-NEC

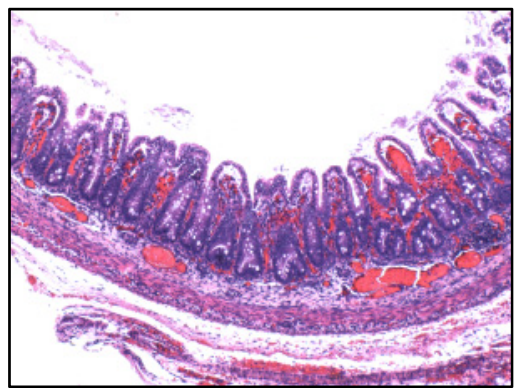

EA-Hydrolyzed protein-NEC

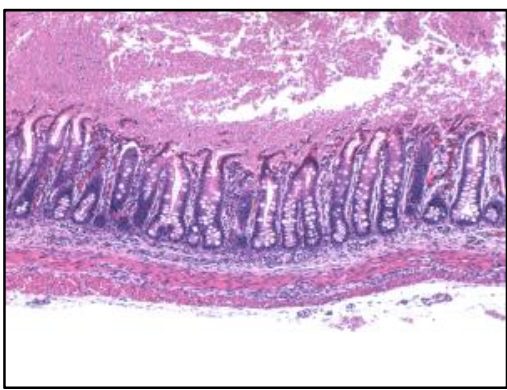

LA-Intact protein-NEC

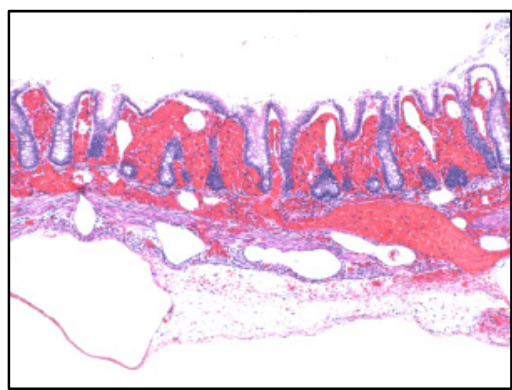

LA-Hydrolyzed protein-NEC

Panel B

Figure S2 